NBER WORKING PAPER SERIES

\title{
CHANGES IN THE WELFARE CASELOAD AND THE HEALTH OF LOW-EDUCATED MOTHERS
}

\author{
Robert Kaestner \\ Elizabeth Tarlov \\ Working Paper 10034 \\ http://www.nber.org/papers/w10034
NATIONAL BUREAU OF ECONOMIC RESEARCH 1050 Massachusetts Avenue
Cambridge, MA 02138
October 2003

The authors thank Rachel Gordon, Chris Ruhm and seminar participants from the University of Illinois at Chicago Sociology Department for their helpful comments. The views expressed herein are those of the authors and not necessarily those of the National Bureau of Economic Research.

(C2003 by Robert Kaestner and Elizabeth Tarlov. All rights reserved. Short sections of text, not to exceed two paragraphs, may be quoted without explicit permission provided that full credit, including $\mathbb{C}$ notice, is given to the source. 
Changes in the Welfare Caseload and the Health of Low-educated Mothers

Robert Kaestner and Elizabeth Tarlov

NBER Working Paper No. 10034

October 2003

JEL No. I12, I13, I38

\begin{abstract}
Declines in the welfare caseload in the late 1990s brought significant change to the lives of many low-educated, single mothers. Many single mothers left welfare and entered the labor market and others re-arranged their lives in order to avoid going on public assistance. These changes may have affected the health and health behaviors of these women. To date, there has been no study of this issue. In this paper, we obtained estimates of the association between the welfare caseload and welfare policies, and three health behaviors - smoking, drinking, and exercise - and two selfreported measures of health - days in poor mental health, and overall health status. The results of our study reveal that changes in the caseload had little effect on measures of health status, but were significantly associated with two health behaviors: binge drinking and regular exercise. The fall in the welfare caseload was associated with a decrease in binge drinking and an increase in regular and sustained physical activity.
\end{abstract}

\author{
Robert Kaestner \\ Institute of Government and Public Affairs \\ University of Illinois at Chicago \\ 815 W. Van Buren Street, Suite 525 \\ Chicago, IL 60607 \\ and NBER \\ kaestner@uic.edu \\ Elizabeth Tarlov \\ Department of Health Policy and Administration \\ University of Illinois at Chicago \\ 815 W. Van Buren Street, Suite 525 \\ Chicago, IL 60607
}




\section{Introduction}

To many observers, welfare reform has been an unqualified success. During the period of reform, welfare caseloads decreased markedly; single mothers began working in unprecedented numbers; and poverty rates did not increase (Haskins 2001; Blank 2002). But a broader evaluation of the effects of welfare reform suggests a more tempered assessment of its success. For example, there is little evidence that welfare reform decreased nonmarital births, or increased marriage rates (Grogger et al. 2002; Joyce et al. 2003). Thus, welfare reform had little effect on the two most important behaviors that create the need for public assistance. In addition, welfare reform may have had some unintended negative consequences. There is evidence that welfare reform has adversely affected adolescent development and academic achievement (Duncan and Chase-Lansdale 2001). And several studies have shown that approximately 40 percent of women who left welfare did not have health insurance in the year following their exit from public assistance (Guyer 2000; Garrett and Holahan 2000; Garrett and Hudman 2002).

Another area where welfare reform may have unintended effects is women's health (O'Campo and Rojas-Smith 1998). Obviously, if welfare reform resulted in a loss of health insurance coverage, then it may have adversely affected women's health, but welfare reform may have affected women's health in other ways. Between 1994 and 2000, changes in welfare policy and a strong economy caused approximately one-fifth of all low-educated, single mothers to transition from welfare-to-work. ${ }^{1}$ The switch from subsidized household work (welfare) to paid employment may affect financial resources, time constraints, and the amount and kind of physical activity, all of which may affect women's health and health behaviors. ${ }^{2}$ For example, single mothers who leave welfare and go to work face greater time pressures and a new set of responsibilities (e.g., arranging for child care) that may increase their psychological distress, which may in turn lead to adoption of coping mechanisms that adversely affect

\footnotetext{
${ }^{1}$ Between 1994 and 2000, the welfare caseload decreased by approximately 60 percent resulting in a 23 percentagepoint decrease in the proportion of low-educated single mothers receiving public assistance. During the same period, there was a 17 percentage-point increase in the proportion of low-educated single mothers who were employed. The figures cited are from the authors' calculation using a sample of women ages 18 to 44 drawn from the Current Population Survey. See also Lerman (2001) for similar figures on employment.

${ }^{2}$ Below, we elaborate on the different types of transitions that comprise the change in welfare caseload.
} 
health such as greater alcohol and tobacco use. On the other hand, employment may result in improved feelings of self worth (self efficacy), increased earnings, and greater access to quality health care through employer-sponsored insurance, and these changes may improve women's health. ${ }^{3}$

To date, there has been no research on the effect of changes in the welfare caseload and welfare reform on women's health. This is unfortunate since health is an essential component of wellbeing and arguably as important as material wellbeing, which has been widely studied vis-à-vis welfare reform. Moreover, evidence as to the effect of welfare reform on women's health would undoubtedly influence the ongoing debate over the reauthorization of current welfare policy. In this paper, we address this shortfall of knowledge. We use data from the 1993 to 2001 Behavioral Risk Factor Surveillance System, and a quasi-experimental research design, to obtain estimates of the associations between changes in the welfare caseload and changes in welfare policy, and the health and health behaviors of low-educated, single mothers.

\section{Changes in the Welfare Caseload and Women's Health}

Declines in the welfare caseload are mechanically determined by a lower rate of entrance to, and a higher rate of exit from, the public assistance program. It is widely believed that changes in the rate of entry and exit and the decline in the welfare caseload during the late 1990s were largely caused by changes in welfare policy and an improving economy (Blank 2002). A higher rate of exit is caused by an increase in two types of transitions off of public assistance: from government paid household work (i.e., welfare) to employment, or what we will refer to as welfare-to-work, and from government paid household work to unpaid household work, or what we will refer to as welfare-to-home. ${ }^{4}$ A lower rate of entry is caused by an increase in three types of transitions: from unpaid household work to employment

\footnotetext{
${ }^{3}$ Hamilton (2002) suggests that one reason why program group members participating in the National Evaluation of Welfare-to-Work Strategies experienced a decrease in the incidence of physical abuse was because their employment resulted in improved self efficacy and self esteem.

${ }^{4}$ Approximately 30 to 35 percent of single mothers who exit welfare are in the welfare-to-home category (Acs et al. 2001; Zedlewski and Loprest 2001). But over half of this group is receiving disability benefits, or has worked recently, or has a working spouse (Zedlewski and Loprest 2001). The remaining portion must have some other source of income (Edin and Lein 1997).
} 
instead of from household work to welfare (home-to-work); from a continuation of unpaid household work (home-to-home) instead of from unpaid household work to welfare; and from a continuation of employment (work-to-work) instead of from employment to welfare. While it may seem incorrect to refer to the continuation of paid work (work-to-work) and the continuation of unpaid household work (home-to-home) as transitions, these states represent transitions vis-à-vis the counterfactual outcomes that involve entering welfare from either paid employment or unpaid household work.

The five types of transitions described above may affect women's health in several ways. As noted earlier, several studies have found that a significant portion — approximately 40 percent—of women who go from welfare-to-work and welfare-to-home are without health insurance in the year following their exit from public assistance (Guyer 2000; Garrett and Holahan 2000; Garrett and Hudman 2002). The decline in insurance coverage is most likely attributable to administrative hurdles associated with enrollment for transitional Medicaid benefits and because many jobs that former welfare recipients obtain do not provide health insurance. However, a more complete analysis of the issue, which includes the experiences of women in all five transition groups, including those that were deterred from entering public assistance, finds much smaller changes in health insurance coverage. Estimates in Kaestner and Kaushal (2003) suggest that only between 5 and 20 percent of low-educated women (mothers) who in the absence of changes in the caseload would have been on welfare and enrolled in Medicaid are without health insurance. While smaller than the estimates from "leaver" studies, these estimates still suggest a possible adverse effect of changes in the welfare caseload on women's health.

It is important to note that policy changes were responsible for only a portion of the decline in the welfare caseload. Therefore, only part of the decline in health insurance associated with a decline in the welfare caseload is due to changes in policy. Estimates from the literature suggest that between 10 to 50 percent of the decline in the welfare caseload is due to policy (Blank 2002). This implies that only 10 to 50 percent of the change in health insurance associated with the decline in the welfare caseload is due to policy. However, it is possible that the consequences of the caseload decline differ by whether the change in the caseload was caused by policy or caused by other factors such as the strong economy. For 
example, those induced to leave welfare because of a policy change may make more use of transitional Medicaid benefits than those who leave for other reasons. Kaestner and Kaushal (2003) find evidence that changes in the caseload due to policy had relatively little effect on health insurance coverage of loweducated single mothers while changes in the caseload due to other causes had a more adverse effect. In general, the effect of welfare reform per se on women's health is expected to be smaller than the effect of broader changes in the welfare caseload on women's health. In the empirical analysis below, we separate these two effects.

The transitions associated with declines in the welfare caseload can affect women's health in other ways than through changes in health insurance. Consider those who go from welfare-to-work. The major change in these women's lives is the replacement of government subsidized household work (i.e., welfare) with paid employment. This may change the level of what we will refer to as employment stress, which includes both physical and psychological components. Clearly, the activities and working conditions (e.g., autonomy) differ between household work, which includes a significant amount of child care, and paid employment. Paid employment may entail more or less physical labor than household work, and there may also be differences in the amount of psychological distress between the two types of labor (Haw 1982; Rosenfield 1989; Lennon and Rosenfield 1992; Lennon 1994; Pugliesi 1995; Ali and Avison 1997). Therefore, the transition from welfare-to-work may affect low-educated, mothers' physical and mental health, although it is not clear in which direction (O'Campo and Rojas-Smith 1998). There are only two studies that explicitly examined the effect of welfare receipt and employment on health. Elliot (1996) found that a woman's self esteem is higher when employed, and lower when on welfare, than it is when she is engaged in unpaid and unsubsidized household work. Similarly, Ensminger (1996) found that welfare recipients had greater levels of psychological distress than similar women not on welfare. ${ }^{5}$

\footnotetext{
${ }^{5}$ These studies are purely descriptive and do not address the question as to whether the transition off of welfare caused a change in health.
} 
Those who go from welfare-to-work may also experience a change in what we will refer to as organizational stress. The transition from welfare-to-work significantly changes the daily routine of mothers. For example, it requires that single mothers arrange for child care, and transportation to and from work and child care. It may also reduce leisure (non-work) time since employment increases the amount of organizing activities, and the reduced leisure may adversely affect health, for example, by reducing the amount of time available for exercise and preparation of nutritious meals (Ruhm 2003). More generally, the transition from welfare-to-work entails a different schedule and different set of responsibilities for carrying out the daily tasks of life than household work, and as a result may affect the amount of psychological distress of women. Previous authors have referred to this as role overload and role conflict, and have investigated the effect of such conditions on women's mental health (Thoits 1986; Reskin and Coverman 1985; Coverman 1989; Lennon 1994; Barnett and Marshall 1992; Ali and Avison 1997).

Changes in employment stress and organization stress may also cause changes in coping strategies that adversely affect health. There is considerable research that greater psychological distress causes people to increase use of alcohol and tobacco (Sayette 1999; Frone 1999; Cooper et al. 1992; Frone et al. 1993; Kassel et al. 2003). In addition, there is evidence that greater psychological distress causes changes in dietary habits (e.g., overeating) that may adversely affect health (Greeno and Wing 1994; Wardle et al. 2000; Oliver and Wardle 1999; Weinstein et al. 1997; Mitchel and Perkins 1998). Again, it is unclear whether the transition from welfare-to-work will positively or negatively affect psychological distress and consequently, whether health behaviors such as smoking and drinking will be adversely affected.

The transition from welfare-to-work may also affect family income and access to government benefits, or what we will refer to as financial stress. And given the well documented positive relationship between income and health, transitions from welfare-to-work may affect women's health through changes in material wellbeing (Smith 1999). Changes in financial stress may also affect mental health and coping mechanisms that adversely affect health (Pearlin and Radabaugh 1976; Peirce et al. 1994; Fenwick and 
Taussig 1994; Ross and Huber 1985; Ruhm 2003). Evidence suggests that there has been little changeif anything a slight improvement — in the material wellbeing of women who have left welfare, and poverty rates have not increased among low-income women in general (Acs et al. 2001; Haskins 2001).

Therefore, it is unlikely that on average women's health has been significantly affected by changes in material wellbeing related to changes in the welfare caseload. But for some women, changes in material wellbeing may have affected health, and even if material wellbeing is unchanged, changes in psychological stress caused by new financial arrangements or financial uncertainty may affect health and health behaviors.

In sum, we have identified three broad pathways, which we refer to as employment stress, organizational stress, and financial stress, by which transitions from welfare-to-work may affect the health and health behaviors of low-educated, single mothers. These pathways are also relevant for the other four types of transitions that comprise the change in the welfare caseload. Each transition represents a potential change in daily activities, working conditions, responsibilities, and financial circumstances that may affect health and health behaviors. This includes transitions that are a continuation of paid employment (work-to-work) and a continuation of unpaid household work (home-tohome). For example, it may be that women who lose a job and who would otherwise enter welfare are induced by policy to find an alternative position that has worse working conditions and lower pay. This may increase employment and financial stress. Similarly, women engaged in household work and who live independently may decide to change living arrangements by taking on a partner or moving back in with parents, and this may affect physical and mental health. ${ }^{6}$

In this paper, we investigate the effect of changes in the welfare caseload on women's health and health behaviors. Notably, we allow the effect of changes in the welfare caseload on women's health and health behaviors to differ depending on whether changes in the caseload were associated with changes in policy or changes in other factors. We focus on low-educated single mothers because they are the group

\footnotetext{
${ }^{6}$ There is considerable evidence that married persons are healthier than unmarried (Lillard and PAnis 1996; Murray 2000). So changes in living arrangements are a potentially important factor affecting health.
} 
most likely affected by changes in the welfare caseload and changes in welfare policy. It is important to recognize that the population affected by changes in the welfare caseload is all women at risk of using public assistance, and not just current or former program participants. Changes in the welfare caseload are caused by changes in entry rates as well as changes in exit rates. Therefore, it is necessary to identify a sample of women at risk of welfare receipt, and low-educated, single mothers are traditionally at the highest risk.

\section{Research Design and Methods}

The objective of this study is to obtain estimates of the association between changes in the welfare caseload and changes in low-educated, single mothers' health and health behaviors. To accomplish this goal we use multivariate regression methods and several years of data from the Behavioral Risk Factor Surveillance System (BRFSS). The BRFSS provides information on women's health and health behaviors, as well as demographic characteristics, socioeconomic status, and state of residence. To this data, we merge information about the size of the welfare caseload, Medicaid eligibility rules, and macroeconomic conditions in a woman's state of residence. Estimates of the association between changes in the welfare caseload and women's health are obtained using ordinary least squares. ${ }^{7,8}$

Ideally, we would like to obtain estimates that can plausibly be considered "causal". Since changes in the welfare caseload were largely caused by changes in policy and changes in economic conditions, events that are beyond the control of individuals and in this sense exogenous, we use a quasiexperimental research design —a pre- and post-test with comparison group — in conjunction with the multivariate regression methods to obtain estimates. Under certain conditions, which we describe below,

\footnotetext{
${ }^{7}$ Sample weights are included in the regression model (i.e., are used as an covariate). This strategy improves the efficiency of the estimates vis-à-vis weighted least squares while simultaneously controlling for any potential bias due to sampling design (Korn and Graubard 1995).

${ }^{8}$ Most of the dependent variables are dichotomous, and therefore, it may be preferable to use maximum likelihood Logit or Probit regression methods. To see whether estimates were sensitive to the method used, we re-estimated some models using the Logit regression procedure. The results from this model were very similar to those presented in the text. Therefore, we chose to present ordinary least squares estimates because of the straightforward interpretation of estimates.
} 
the pre- and post-test with a comparison group research design will yield "causal" estimates. The starting point of this empirical approach is the regression model that links changes in health outcomes to changes in the welfare caseload. This model is specified as follows:

(1)

$$
\begin{aligned}
& \mathrm{H}_{\mathrm{ijt}}=\alpha+\beta_{\mathrm{j}}+\left(\beta_{\mathrm{j}} * \delta_{\mathrm{t}}\right)+\gamma \text { Caseload }_{\mathrm{jt}}+\mathrm{Z}_{\mathrm{jt}} \Phi+\mathrm{X}_{\mathrm{ijt}} \Gamma+\mathrm{u}_{\mathrm{ijt}} \\
& \mathrm{i}=1, \ldots, \mathrm{N} \text { (persons) } \\
& \mathrm{j}=1, \ldots, 51 \text { (states) } \\
& \mathrm{t}=1994, \ldots, 2001 \text { (years) }
\end{aligned}
$$

In equation (1), health $\left(\mathrm{H}_{\mathrm{ijt}}\right)$ of woman $\mathrm{i}$ in state $\mathrm{j}$ and year $\mathrm{t}$ is a function of the welfare caseload in state $\mathrm{j}$ and year t; time-varying state characteristics $\left(Z_{j t}\right)$ such as the Medicaid income eligibility threshold, the unemployment rate, and per-capita income; individual characteristics $\left(\mathrm{X}_{\mathrm{ijt}}\right)$ such as age, race and family composition; state fixed effects $\left(\beta_{j}\right)$; and state-specific time trends $\left(\beta_{\mathrm{j}} * \delta_{\mathrm{t}}\right){ }^{9}{ }^{9}$ It is important that we control for economic conditions because changes in the economy may affect health in ways besides through changes in the welfare caseload.

One disadvantage of equation (1) is that it does not differentiate between the effect of changes in the welfare caseload due to policy and the effect of changes in the welfare caseload due to other factors such as a strong economy. Evidence suggests that most of the change in the caseload was not due to policy, particularly prior to the implementation of Personal Responsibility and Work Opportunity Reconciliation Act (PRWORA) in 1996 (Blank 2002). Therefore, estimates of the association between the welfare caseload and health in equation (1) represent upper bound estimates of the effect of welfare reform. For example, if welfare reform was responsible for one-third of the decline in the caseload, then estimates from equation (1) may be divided by three to derive the effect of welfare reform. However, it is possible that those who leave welfare because of government policy may have different experiences than those who leave for other reasons such as robust economic growth. If so, then it is not appropriate to simply apportion the effect of the caseload to estimate the effect of welfare reform.

\footnotetext{
${ }^{9}$ In the empirical analysis, we use a quadratic specification for the time trend.
} 
A preferable model would be one in which we allowed the effect of the welfare caseload on health to differ by the cause of the change in the caseload, as in the following:

(2) $\mathrm{H}_{\mathrm{ijt}}=\alpha+\beta_{\mathrm{j}}+\left(\beta_{\mathrm{j}} * \delta_{\mathrm{t}}\right)+\gamma_{1} \operatorname{Case}(\text { Policy })_{\mathrm{jt}}+\gamma_{2} \operatorname{Case}(\text { Re sidual })_{\mathrm{jt}}+\mathrm{Z}_{\mathrm{jt}} \Phi+\mathrm{X}_{\mathrm{ijt}} \Gamma+\mathrm{u}_{\mathrm{ijt}}$

In equation (2), the variables Case(Policy) and Case(Residual) are the portions of the welfare caseload related to policy and other factors, respectively. The coefficient on Case(Policy) provides an estimate of the effect of welfare reform on health. The two caseload variables in equation (2) are derived from the following:

(3) Caseload $_{\mathrm{jt}}=\sigma_{\mathrm{j}}+\rho_{\mathrm{t}}+\lambda_{1} \mathrm{TANF}_{\mathrm{jt}}+\lambda_{2}(\mathrm{AFDC}$ Waiver $)+\mathrm{Z}_{\mathrm{jt}} \Psi+\mathrm{v}_{\mathrm{jt}}$

(4) $\operatorname{Case}(\text { Policy })_{\mathrm{jt}}=\lambda_{1}(\mathrm{TANF})_{\mathrm{jt}}+\lambda_{2}(\text { AFDC Waiver })_{\mathrm{jt}}$

(5) Case $(\text { Re sidual })_{j t}=$ Caseload $_{j t}-$ Case $(\text { Policy })_{j t}$

Equation (3) is the structural model determining the welfare caseload, which we assume depends on state and federal welfare policies, AFDC (Aid to Families with Dependent Children) waivers and TANF (Temporary Assistance to Needy Families), and other factors. Equations (4) and (5) simply decompose the caseload into that due to policy [Case(Policy)] and that due to other factors [Case(Residual)]. To estimate equation (2) requires that we first estimate equation (3) and then construct the variables of interest. However, obtaining estimates of the effect of policy on the welfare caseload has been a controversial area of research (Blank 2002). The fundamental problem has been that it is difficult to distinguish the effect of policy from the effect of other factors such as the unemployment rate. ${ }^{10}$ If equation (3) is incorrectly specified, then using estimates from it to construct the variables Case(Policy) and Case(residual) will result in biased estimates of equation (2). In effect, any specification error in equation (3) will be transmitted to equation (2).

We can avoid this problem by substituting equation (4) into (5), the result of that into equation (2), and estimating the following model:

\footnotetext{
${ }^{10}$ Our task would be particularly difficult since we would need to estimate state-specific effects of policy so that the predicted caseload variables would have state-time variation. Restricting the effect of policy to be constant across states would leave no state-time variation and only limited time variation in the predicted caseload variable.
} 


$$
\begin{aligned}
\mathrm{H}_{\mathrm{ijt}}= & \alpha+\beta_{\mathrm{j}}+\left(\beta_{\mathrm{j}} * \delta_{\mathrm{t}}\right)+\left(\gamma_{1}-\gamma_{2}\right) \lambda_{1}(\mathrm{TANF})_{\mathrm{jt}}+\left(\gamma_{1}-\gamma_{2}\right) \lambda_{2}\left({\text { AFDC Waiver })_{\mathrm{jt}}+}+\right. \\
& \gamma_{2} \text { Caseload }_{\mathrm{jt}}+\mathrm{Z}_{\mathrm{jt}} \Phi+\mathrm{X}_{\mathrm{ijt}} \Gamma+\mathrm{u}_{\mathrm{ijt}}
\end{aligned}
$$

Equation (6) allows us to test whether the effect of changes in the caseload caused by welfare policy $\left(\gamma_{1}\right)$ differs from the effect of changes in the caseload due to other factors $\left(\gamma_{2}\right)$, but it avoids having to estimate equation (3). The coefficients on the welfare policy variables (TANF and AFDC Waivers) measure the difference between the effect of the caseload due to policy and the effect of the caseload due to other factors. Note that $\lambda_{1}$ and $\lambda_{2}$, the effects of policy on the welfare caseload, are expected to be negative, so the coefficients on the policy variables will have the opposite sign of the true difference. Another advantage of equation (6) is that it allows changes in the caseload associated with TANF and AFDC waivers to have different effects on health status.

To a large extent, equations (1) and (6) address the fundamental identification problem associated with this analysis, which is to isolate the effect of changes in the welfare caseload or changes in government policy from other determinants of women's health (or health behaviors) that vary over time, across states and over time within states. The primary remaining weakness is that there may be omitted variables that vary by state and year that affect health of low-educated mothers and that are correlated with the welfare caseload or government policy.

To address this problem, we rely on a comparison group approach. To implement this approach, we estimate equations (1) and (6) for two groups: those likely to participate in the cash assistance program, and therefore likely to be affected by welfare reform, and those unlikely to participate in the cash assistance program and therefore unlikely to be affected by welfare reform. We refer to the former as the target group and the latter as the comparison group. A critical assumption underlying this strategy is that in the absence of welfare reform (e.g., changes in the welfare caseload) changes in health and health behaviors would be similar between the target and comparison groups.

The counterpart of equation (1) for the comparison group is the following:

$$
\mathrm{H}_{\mathrm{ijt}}=\widetilde{\alpha}+\widetilde{\beta}_{\mathrm{j}}+\left(\widetilde{\beta} * \widetilde{\delta}_{\mathrm{t}}\right)+\widetilde{\gamma} \text { Caseload }_{\mathrm{jt}}+\mathrm{Z}_{\mathrm{jt}} \widetilde{\Phi}+\mathrm{X}_{\mathrm{ijt}} \widetilde{\Gamma}+\mathrm{e}_{\mathrm{ijt}}
$$


The key point to note about equation (7) is that the coefficient on the welfare caseload variable, $\widetilde{\gamma}$, should be zero since this group is by definition not at risk of welfare receipt and changes in the welfare caseload should not affect their health or health behaviors. A non-zero estimate of this parameter indicates that there are omitted variables that affect health that are correlated with the welfare caseload. Therefore, we can subtract this effect from the corresponding estimate $(\gamma)$ in equation (1) to obtain an estimate of the effect of the caseload on health that controls for these omitted variables. This approach is commonly referred to as difference-in-differences (DD) and estimates can be obtained directly by combining equations (1) and (7) and estimating the combined model using a pooled sample of target and comparison group members. The only identifying restriction is that in the absence of welfare reform, unmeasured state-year influences on health would affect the target and comparison group equally. If this assumption is valid, then the difference $(\gamma-\tilde{\gamma})$ measures the causal effect of the welfare caseload on the health and health behaviors of low-educated, single mothers.

Clearly, the choice of target and comparison groups is crucial to the success of the pre- and posttest with comparison group design. Identifying a target group is relatively straightforward. Welfare reform was intended to decrease the welfare caseload, which consists primarily of low-educated, single mothers. Accordingly, we define our target group to be single mothers with 12 or fewer years of education. ${ }^{11}$ The comparison group is more difficult. We choose two groups: low-educated (education $\leq$ 12 years), married mothers, and low-educated men. ${ }^{12}$ Due to eligibility rules, only a small portion of the

\footnotetext{
${ }^{11}$ It is possible that welfare reform affected fertility and marriage, so selecting the sample on these characteristics may result in changes in sample composition. Based on existing evidence, however, we believe the bias due to sample selection will be insignificant. See Grogger et al. (2002) for evidence on the effect of welfare reform on marriage and fertility.

${ }^{12}$ A third potential comparison group is low-educated single women without children. We do not use this group for two reasons. First, the BRFSS does not identify "own" children, only whether children live in the household. Therefore, the current target group will consist mainly of low-educated single mothers, but will also include loweducated single women without children. Second, low-educated single women without children may be affected by welfare reform because a significant portion is at risk of welfare receipt since they are at risk of having a non-marital birth.
} 
comparison groups are at risk of welfare receipt, and for the most part persons in these two groups are unaffected by changes in the welfare caseload. ${ }^{13}$

A cursory way to assess the adequacy of the comparison groups is to compare them to the target group. Ideally, we would like the mean characteristics of the comparison groups to be quite similar to the mean characteristics of the target group. These figures are shown in Table $1 .{ }^{14} \mathrm{We}$ focus on the initial years of our analysis, 1993-94, which predated most welfare reform legislation. Figures in Table 1 indicate that the target and comparison groups are approximately the same age and have similar levels of education, which is not that surprising since age and education were used to select the samples. However, the target group has a larger proportion of Black, non-Hispanic persons. As would be expected, the target group and comparison groups differ by family structure, and employment status. Low-educated men (comparison) have fewer children than low-educated mothers (target), and married mothers (comparison) have more adults in the household than unmarried mothers (target). Interestingly, the employment rates of married and unmarried mothers are approximately the same, but low-educated men have somewhat higher employment rates. In regard to the dependent variables, which we describe in more detail below, the target and comparison groups are relatively similar except for binge drinking behavior and mental health. Low-educated men are more likely to binge drink then either married or unmarried mothers, and married mothers are slightly less likely to binge drink than unmarried mothers. In regard to mental health, women report a greater incidence of poor mental health days than men, but married and unmarried mothers have similar means. In general, the target and comparison groups have relatively similar means, and based on this limited criterion, the comparison groups appear to be adequate.

\section{Data}

Our primary data source is the Behavioral Risk Factor Surveillance System (BRFSS) which provides information on current health behaviors and health status. The BRFSS is an ongoing data

\footnotetext{
${ }^{13}$ Because a portion of the comparison group may be affected and portion of the target group may be unaffected by changes in the welfare caseload, estimates of the "treatment" effect will be biased toward zero.

${ }^{14}$ Appendix Table 1 presents means calculated from all available years of data.
} 
collection program designed to monitor behavioral risk factors in non-institutionalized adults in the United States (CDC). Designed to collect state-level data, surveys are fielded by the states through telephone interviews using a probability sampling design. ${ }^{15}$ In our multivariate regressions, we use weights developed by the BRFSS to make the data representative of state populations. We use data from survey years 1993 through 2001, a period that spans welfare reform. These data were collected by all 50 states and the District of Columbia, with the exception that Wyoming did not participate in 1993.

We focus on low-educated women because this is the target group of welfare reform. Specifically, we define the target group to be unmarried mothers between the ages of 19 and 39 who have 12 or fewer years of education. As previously noted, we use two comparison groups in the analysis: loweducated (education $\leq 12$ years), married mothers and low-educated (education $\leq 12$ years) men, regardless of marital and parental status. Both comparison groups are restricted to individuals between the ages of 19 and 39.

The BRFSS contains most of the data necessary to complete our analysis. We focus on three health behaviors, cigarette smoking, alcohol intake, and exercise and on two self-assessed health status measures, mental health and general health. ${ }^{16}$ More specifically, the outcomes we study are daily smoking, binge drinking, engaging in regular and sustained physical activity, mental health reported as being "not good" for one or more days in the last month, and reporting fair or poor health (rather than good, very good, or excellent health).

Due to changes in tobacco-related questions in the BRFSS during the study years, the daily smoking variable was constructed slightly differently in the three survey years $1993-1995$, than it was in the remaining six years. From 1996 on, respondents were specifically asked whether they smoke every day. For 1993, we coded respondents as daily smokers if they reported current smoking and did not respond "Don't smoke regularly" to a question asking number of cigarettes currently smoked per day.

\footnotetext{
${ }^{15}$ Sampling designs have varied somewhat across survey years and states. All 50 states and the District of Columbia whose data are included in this study used a disproportionate stratified sample design in 2001 Samples are identified through telephone-based methods (CDC, 2001).

${ }^{16}$ We often used two different measures of each health behavior, and we report on these findings below. For example, we use a dichotomous indicator of binge drinking and the number of binge drinking occasions.
} 
For 1994 and 1995, current smokers were coded as daily smokers if they indicated that they smoked on 30 of the last 30 days.

Survey questions on alcohol use and exercise are included on a rotating basis in the core questionnaire required of all participating states. For this reason, we use data on those behaviors only from the odd years, in the case of alcohol, and the even years, in the case of exercise. The binge drinking variable was constructed as a dichotomous variable from responses to a question asking number of times in the last month that the respondent had 5 or more drinks on an occasion. Anyone giving an answer of one time or more to this question was coded as "1" on binge drinking. Nondrinkers and those who answered zero were coded as " 0 ". The dichotomous variable indicating regular and sustained exercise is constructed by the BRFSS from responses to several questions regarding physical activity habits. Criteria for coding has varied slightly over the survey years but generally indicates engaging in physical activity for 30 or more minutes 5 or more times per week, regardless of how vigorous is the activity. ${ }^{17}$

The reliability of BRFSS data has been investigated in several test-retest studies (e.g., Shea, et al., 1991; Stein, et al., 1995). Some degree of misreporting of behaviors perceived to be socially undesirable, like smoking and heavy drinking, is known to occur. However, studies comparing self-reported to biochemical measures have generally found a high degree of sensitivity and specificity of the self-report measures (Patrick, et al., 1994; Poikolainen et al., 2002; Wagenknecht, et al., 1992). Heavy drinkers underestimate their alcohol intake more than light drinkers (Poikolainen, Podkletnov, and Alho). Our measure of binge drinking, because it is a simple dichotomous measure indicating zero, versus one or more binge drinking occurrences, does not rely on reporting accuracy along increasing levels of intake. Also, there is no obvious reason to think that reporting accuracy within any of the three groups we have identified should have varied over time or with changes in welfare caseload and so, for these reasons, should not affect our results.

\footnotetext{
${ }^{17}$ BRFSS documentation on the calculated physical activity variable contains the following note: "See article 'Description of the Scoring System for the Physical Activity Questions of the Behavioral Risk Factor Surveillance System' written by Carl Caspersen, $\mathrm{PhD}$ (770-488-5513) for computation of the scoring system (activity levels)" (CDC, 2000).
} 
The BRFSS also contains basic demographic information that can be used to construct control variables. As noted, we define our target and comparison groups on the basis of education and marital status. Other personal characteristics included in the model include: household size (number of children and number of adults), age, race, and high school graduation or GED.

A limitation of BRFSS data is that it does not specifically identify parents. Rather, questions related to children inquire about children in the household. For the purposes of this analysis we assume that anybody indicating children in the household was a parent. This would not have affected the second group, men, because that group included all low-educated men, aged 19-39. However, since we use these data to identify single and married mothers, this will have resulted in an unknown degree of misspecification of the target and first comparison groups. To investigate its likely impact on our results, we identified a subgroup of women who, by virtue of their indicating that only one adult lived in that household, we felt certain were true single mothers. We estimated regression models identical to those we report on below using this group. The results from this analysis were substantively comparable, as when we used the whole sample of single women with children in the household.

Finally, the BRFSS provides respondents' state of residence, which allows us to append statelevel information. We use the following: state and federal welfare policy; monthly state welfare caseload; Medicaid income eligibility threshold; current unemployment rate and one-year lag; and real per-capita income. ${ }^{18}$ State Medicaid eligibility variables are defined on the basis of Medicaid eligibility of pregnant women; we use the following categories: 0 to 133 percent of federal poverty line, 134 to 199 percent of federal poverty line, and above 200 percent of the federal poverty line.

The monthly welfare caseload data is taken from the Administration for Children and Families. We measure the caseload as the natural logarithm of the caseload. It is matched to the month prior to the BRFSS interview. To best reflect employment conditions affecting survey respondents, those

\footnotetext{
${ }^{18}$ Unemployment statistics are from the U.S. Department of Labor, Bureau of Labor Statistics, http://www.bls.gov/data/home.htm/. State Medicaid eligibility were provided by Aaron Yellowitz and updated with data from the National Governor's Association, in their annual Maternal and Child Health (MCH) Update reports, http://www.nga.org/center/divisions/1,1188,C_ISSUE_BRIEF^D_5114,00.html/.
} 
interviewed in the first half of the year were assigned the employment rate for the prior year while those interviewed in the last six months of the year were assigned the rate for that year. The data on welfare policies is drawn from Assistant Secretary for Planning and Evaluation of the Department of Health and Human Services, as well as from the Urban Institute

(www.urban.org/content/Research/NewFederalism/Data/StateDatabase/StateDatabase.htm) and the State Documentation Project of the Center on Budget and Policy Priorities (www.cbpp.org).

We follow the earlier literature on the effects of welfare reform and use dummy variables for whether a state had implemented an AFDC waiver or TANF at the time (month) of the BRFSS interview. We set the waiver variable to zero when TANF is implemented. However, we also use a more detailed specification of welfare policy; specifically, we create three dummy variables that indicate whether a state had implemented time-limited benefits, had an exemption from work requirements only for women with children under six-months of age, and had full financial sanctions for non-compliance.

\section{Results}

Tables 2 through 6 present ordinary least squares regression estimates of the parameters of equations (1) and (6) for the target and comparison groups. We also present difference-in-differences (DD) estimates. We estimate two versions of equation (6). One that characterizes welfare reform using dummy variables indicating that a state has implemented an AFDC waivers or TANF, and another that characterizes welfare reform using dummy variables indicating that a state has implemented different aspects of reform: time-limited benefits, strict work exemption policy, and a strict sanction for noncompliance policy. Standard errors have been constructed under the assumption that observations within states may not be independent (Bertrand et al. 2002). We also include the sampling weight as an independent variable to account for sampling design.

We begin by examining the relationship between the welfare caseload and three health behaviors: smoking, drinking, and exercise. Table 2 presents estimates of the association between the welfare caseload and welfare policies and the probability of daily smoking. Panel one contains estimates of 
equation (1). These estimates indicate that the association between the natural logarithm of the welfare caseload and the probability of daily smoking is not statistically significant for any of the samples. Further the magnitudes of the estimates are quite small. For example, according to data from the Administration for Children and Families (http://www.acf.dhhs.gov/news/tables.htm) between January 1996 and June 2000, the welfare caseload declined by $0.74 \log$ points (52 percent). A decline of this magnitude is associated with a 1.6 percentage point, or four percent, decline in daily smoking among loweducated, unmarried mothers (target group). Other estimates in panel one imply similarly small associations. Difference-in-difference estimates are also not statistically significant and small.

In panels two and three of Table 2, we present estimates of equation (6). The addition of the welfare policy variables makes little difference. The estimates of the association between the welfare caseload and daily smoking are not statistically significant and remain small in magnitude. Estimates associated with the policy variables are mostly not statistically significant. The exception is the indicator for a strict financial sanction policy. The estimate is positive, which indicates that changes in the caseload due to sanction policy had a less positive association with daily smoking than did changes in the caseload due to other reasons. In fact, the algebraic relations embedded in equation (6) suggest that changes in the caseload due to sanction policy were negatively associated with daily smoking; a decrease in the caseload due to sanction policy is associated with an increase in daily smoking. To see how we reached this conclusion, note that the coefficient on the sanction variable is 0.027 and is equal to the following: $\left(\gamma_{1}-\gamma_{2}\right) \lambda_{1}$ (from equation 6). $\gamma_{1}$ is the association between changes in the caseload due to sanctions and daily smoking, and $\gamma_{2}$ is the association between changes in the caseload due to other factors and daily smoking. Estimates of equation (6) provide an estimate of $\gamma_{2}$, which is equal to 0.036 (Table 2). $\lambda_{1}$ is the change in the $(\log )$ caseload due to sanction policy. If we assume that it is equal to 0.2 , which is in the range reported by Blank (2002) and which implies that sanctions were responsible for approximately 20 percent of the change in caseload, then $\gamma_{1}$ is equal to -0.099 . Thus, a $0.74 \log$ point, or 52 percent, decrease in the welfare caseload as a result of financial sanctions would increase daily 
smoking by 7.3 percentage points, or 19 percent. We note, however, that the estimate associated with sanctions is also statistically significant for married mothers and that the difference-in-differences estimate is virtually zero. Thus, we conclude that changes in the welfare caseload, whether because of policy or for other reasons are not associated with daily smoking of low-educated single mothers.

The next health behavior we examine is binge drinking. Table 3 presents the estimates of the association between the welfare caseload and the probability of binge drinking in the last month. Estimates in panel one show that changes in the welfare caseload are positively associated with binge drinking for single mothers. A $0.74 \log$ point decline in the welfare caseload is associated with a 4.2 percentage point, or 30 percent, decrease in the probability of binge drinking. Moreover, the welfare caseload is not associated with the binge drinking of low-educated, married mothers or low-educated men. The difference-in-difference estimates are positive and significant and of the same approximate magnitude as the estimate associated with the target group. This provides evidence that the significant association between changes in the welfare caseload and binge drinking is not general, but specific to the low-educated single mothers - the group most likely to be affected by changes in the caseload. If the identifying assumption of the difference-in-difference analysis holds, this association can be considered causal. Decreases in the welfare caseload caused low-educated mothers to decrease their binge drinking by a significant amount.

The estimates in panels two and three of Table 3 reveal that the coefficients associated with the policy variables are not statistically significant. Moreover, the addition of these variables had relatively little effect on the estimate of the effect of the welfare caseload. This implies that the association between changes in the caseload and binge drinking does not differ by the underlying cause of the caseload change. The binge drinking behavior of low-educated single mothers who changed welfare status because of policy is the same as the binge drinking behavior of low-educated mothers who changed welfare status for other reasons. We also estimated models in which the dependent variable was the number of binge drinking occasions in the last month. The results form this analysis were qualitatively the same as those reported except that estimates were not as precise and the p-values were higher. 
Table 4 presents estimates of the association between changes in the welfare caseload and the probability of engaging in regular and sustained physical activity. In this case, estimates in panel one indicate that changes in the caseload are negatively associated with being regularly physically active among single mothers. For the comparison groups, changes in the caseload are positively related to physical activity. Accordingly, the DD estimates are negative, and when men are used as a comparison group, statistically significant. However, the DD estimates associated with both comparison groups are of the same magnitude. DD estimates indicate that the decline in the welfare caseload between January 1996 and June 2000 (52 percent or $0.74 \log$ points) is associated with approximately a four percentage point, or 27 percent, increase in the probability of engaging in regular and sustained physical activity. We also obtained estimates of the association between welfare caseload and the probability of engaging in any leisure-time physical activity. In this case, the caseload was negatively associated with physical activity among single mothers, but not statistically significant. DD estimates related to this outcome were close to zero.

Estimates in panel two and three suggest similar effects, although DD estimates associated with some of the policy variables are relatively large. For example, the coefficient on time limits is 0.039 and statistically significant and the estimate of the effect of the caseload is much smaller than in panel one. The coefficient on time limits implies that changes in the welfare caseload due to time-limited benefits are negatively associated with regular physical activity. The implied estimate is -0.22 , which is much larger than the estimate associated with the caseload itself. ${ }^{19}$ Thus changes in the welfare caseload due to timelimited benefits have a larger (more negative) effect on physical activity than changes in the caseload due to other factors. ${ }^{20}$ A similar result pertains to the coefficient on AFDC waivers. The positive coefficient, which approaches statistical significance, suggests that changes in the caseload due to AFDC waivers had a larger (more negative) effect on physical activity than changes in the caseload due to other reasons.

\footnotetext{
${ }^{19}$ The estimate was obtained using equation (6) and similar assumptions as those described in the text.

${ }^{20}$ We recognize that the estimate, -0.22 , may be implausibly large, but we also recognize that the calculations used to obtain the estimate are somewhat crude and subject to significant sample variation.
} 
We now turn to an examination of the association between the welfare caseload and health status, which we measure in two ways: the probability of reporting a non-zero number of days in poor mental health in the last month; and the probability of reporting fair or poor health. ${ }^{21}$ Table 5 presents estimates of the association between changes in the welfare caseload and the probability of having poor mental health. None of the estimates associated with the welfare caseload are statistically significant, and all are small in magnitude. The same is true in Table 6; all estimates of the association between the welfare caseload and poor health status are not significant and small in magnitude. Overall, estimates in Tables 5 and 6 indicate that changes in the welfare caseload are not associated with self-reported mental health or self-reported general health.

\section{Conclusions}

Declines in the welfare caseload in the late 1990s brought significant change to the lives of many low-educated single mothers. Many single mothers left welfare and entered the labor market and others re-arranged their lives in new ways in order to avoid going on public assistance. ${ }^{22}$ These changes may have affected the health and health behaviors of these women. Switching from unpaid household work to paid employment may affect the amount of physical activity and psychological stress, and it may alter financial circumstances, all of which may affect health and health behaviors. Similarly, other strategies to avoid public assistance such as cohabitation with a partner or family member may affect physical and mental health, and health behaviors. Moreover, because welfare is an important entry point for Medicaid, changes in the welfare caseload may have affected health insurance coverage, which may affect health.

To date, there has been no study of this issue, which is surprising because of the central role that health plays in personal wellbeing. In contrast, there has been an outpouring of research on the effects of

\footnotetext{
${ }^{21} \mathrm{We}$ also examined the effect of welfare reform on the probability of being overweight. Results from this analysis were similar to those reported below—estimates of the association were not statistically significant and small in magnitude.

${ }^{22}$ One way to avoid public assistance is to alter living arrangements including cohabitating with a partner, or coresiding with parents and other family members. However, there is little evidence as to the effect of welfare reform on living arrangements (Bitler et al. 2002; Grogger et al. 2002).
} 
changes in the welfare caseload and welfare reform on material wellbeing. In this paper, we addressed this shortfall of research. We obtained estimates of the association between the welfare caseload and welfare policies, and three health behaviors—-smoking, drinking, and exercise — and two self-reported measures of health - days in poor mental health, and overall health status. Importantly, we allowed the association between changes in the caseload and these outcomes to differ by whether the change in the caseload was due to policy or other factors such as a strong economy. In addition, we employed a research design that under certain assumptions yields causal estimates of the association between the welfare caseload and health. Our attempt to obtain causal estimates is important because policy development and evaluation requires knowledge of causal pathways. This makes our study relevant to the current Congressional debate over the renewal of the Personal Responsibility and Work Opportunity Reconciliation Act (PRWORA).

The results of our study reveal that changes in the caseload had little effect on measures of health status, but were significantly associated with two health behaviors: binge drinking and regular exercise. Changes in the welfare caseload were positively and significantly related to binge drinking. Decreases in the welfare caseload such as those that occurred between January 1996 and June 2000 were associated with a 3.7 percentage point, or 27 percent, decrease in the probability of binge drinking in the past month among low-educated single mothers. Similar results were also found when we studied the number of binge drinking occasions in the past month instead of the incidence of binge drinking. Further, estimates suggested that the association between changes in the welfare caseload and binge drinking did not differ by the underlying cause of the caseload change. Changes due to policy had similar effects as changes due to other factors such as the economy.

Interestingly, the relationship between changes in the welfare caseload and binge drinking was virtually unchanged when we added employment status to the regression model. The transition from welfare to paid employment, which includes what we have referred to as welfare-to-work and work-towork transitions, was responsible for a significant portion of the decline in the caseload. Therefore, we hypothesized that the inclusion of employment status in the model would greatly reduce the association 
between welfare caseload and binge drinking since much of the change in the caseload is associated with an increase in paid employment. The fact that it did not suggests that the association between changes in the welfare caseload and binge drinking is not a consequence of greater employment. In fact, employment status (i.e., employed) was positively and significantly related to binge drinking for loweducated, single mothers (estimates not shown). This is inconsistent with the positive association between the welfare caseload and binge drinking. If much of the decline in the caseload was employment related, and employment is positively related to binge drinking, then decreases in the caseload should increase binge drinking, which is not what we found. ${ }^{23}$ The inconsistency is most likely due to the fact that employment status is not exogenous; employed persons differ from unemployed persons in unobserved ways. Therefore, the relationship between employment status and binge drinking is likely confounded by omitted factors. In contrast, declines in the welfare caseload are much more likely to be associated with exogenous changes in employment since most of the decline was due to policy changes and a strong economy - two exogenous factors. The fact that the association between binge drinking and the welfare caseload was not diminished by the inclusion of employment status implies that the decrease in binge drinking associated with the decline in the caseload occurred equally among those whose transitions ended in employment and those whose transitions did not end in employment.

We hypothesized that changes in the caseload would affect alcohol use primarily because of changes in psychological distress. If this hypothesis is correct, the findings suggest that declines in the caseload were associated with less distress. However, we did not find an improvement in mental health, as currently measured. We also did not observe any change in the effect of the caseload when we included the mental health indicator in the regression. An alternative explanation is that changes in the caseload may have affected coping skills that resulted in less binge drinking. It is clear from this discussion, that further study is required to identify the underlying reason for the association between changes in the welfare caseload and changes in binge drinking.

\footnotetext{
${ }^{23}$ The positive effect of employment on binge drinking is consistent with evidence in Ruhm (1995) that alcohol sales are procyclical - increase when employment increases.
} 
Changes in the welfare caseload were also significantly associated with the probability of engaging in regular and sustained physical activity. Decreases in the caseload were associated with increases in physical activity. In this case, there was some evidence that changes in the caseload due to policy had larger (more negative) effects than changes in the caseload due to other reasons. However, the coefficients on the policy variables in these models did not have consistent signs and most were not statistically significant. Therefore, we view this evidence as at best suggestive. Here too, the association between changes in the caseload and physical activity was unaffected by the addition of employment status to the model, but in this case, the estimate associated with employment status was not statistically significant. ${ }^{24}$ So again, the association between changes in the caseload and physical activity occurred equally among women whose transition ended in employment and women whose transition did not end in employment.

Intuition suggests that decreases in the caseload would be associated with less exercise, as time constraints become more burdensome because of the greater labor market commitment. We find the opposite. But we also do not find that the increase in physical activity is a consequence of greater employment. So those who transition to employment are not the only women who increased their physical activity. Again, our analysis is unable to identify the underlying reasons and we can only conjecture about the possible mechanisms. More study is needed to uncover the mechanisms and to validate our findings.

Overall, our results suggest that the recent declines in the caseload have lead to healthier lifestyles among low-educated single mothers. Decreases in the caseload are associated with less binge drinking and greater exercise. Notably, the improvements in lifestyle associated with the decrease in the welfare caseload were not due to greater employment. This suggests that lifestyle improvements were experienced by women in all of the five transition groups described above, and not just those that made the transition to paid employment. We also explored whether changes in the caseload due to welfare

\footnotetext{
${ }^{24} \mathrm{Ruhm}$ (2000) showed that a decrease in unemployment rate (greater employment) is associated with a decrease in exercise. So we expected to find that employment was negatively related to regular physical exercise. We did not.
} 
reform policies had a differential effect on health and health behaviors than changes in the caseload due to other factors. On this point the results were mixed. In the case of binge drinking, there did not appear to be any difference between the broad categories of "welfare leavers". But for physical activity, there was some evidence that those who left the caseload because of policy (e.g., time-limited benefits) were more likely to increase their physical activity than those who left the caseload for other reasons. The evidence on this point was not robust and therefore suggests that this conclusion remain tentative.

In sum, the results of this analysis suggest that welfare reform and the decrease in the welfare caseload have not adversely affected the health of low-educated, single mothers. This finding is consistent with research by Kaestner and Kaushal (2003) who find that welfare reform had modest adverse effects on the health insurance coverage of this group. These findings should prove useful in the current debate over the merits of the 1996 federal welfare reform law and whether it should be renewed. 


\section{References}

Acs, Gregory, Pamela Loprest, and Tracey Roberts. 2001. "Final Synthesis Report of Findings from ASPE 'Leavers' Grants.” Washington, D.C.: Urban Institute Press. Available at http://aspe.hhs.gov/search/hsp/leavers99/synthesis02/index.htm

Ali, Jennifer, and William R. Avison. 1997. "Employment Transitions and Psychological Distress: The Contrasting Experiences of Single and Married Mothers." Journal of Health and Social Behavior 38:345-362.

Barnett, Rosalind C., and Nancy L. Marshall. 1992. "Worker and Mother Roles, Spillover Effects, and Psychological Distress." Women and Health 18:9-40.

Bertrand, M., Duflo, E., and Mullainathan, S. 2002. "How Much Should We Trust Difference-inDifferences Estimates?” NBER WP 8841. Cambridge, MA: National Bureau of Economic Research.

Bitler, Marianne, Jonah Gelbach, and Hillary Hoynes. 2002. "The Impact of Welfare Refom on Living Arrangements." NBER Working Paper \#8784, National Bureau of Economic Research, Cambridge, MA.

Blank, R. 2002. "Evaluating welfare reform in the United States." Journal of Economic Literature 40(4):1-43.

Centers for Disease Control and Prevention (CDC). Behavioral Risk Factor Surveillance System Survey Data. Atlanta, Georgia: U.S. Department of Health and Human Services, Centers for Disease Control and Prevention, 1993-2001.

Centers for Disease Control and Prevention. 2001. "Overview: BRFSS 2001." http://www.cdc.gov/brfss/ti-surveydata2001.htm.

Centers for Disease Control and Prevention. 2000. "Calculated Variables in Data Files." http://www.cdc.gov/brfss/ti-surveydata2000.htm.

Cooper, M. Lynne, Marcia Russell, Jeremy B. Skinner, Michael R. Frone, and Pamela Mudar. 1992. "Stress and Alcohol Use: Moderating Effects of Gender, Coping, and Alcohol Expectancis." Journal of Abnormal Psychology 101:139-152.

Coverman, Shelley. 1989. "Role Overload, Role Conflict, and Stress: Addressing Consequences of Multiple Role Demands.” Social Forces 67:965-982.

Duncan, Greg J., P. and Lindsay Chase-Lansdale. 2001. "Welfare Reform and Children's Well-being." In The New World of Welfare, edited by Blank, Rebecca M. and Ron Haskins. Washington, D.C.: Brookings Institution Press. 391-412.

Elliott, Marta. 1996. "Impact of Work, Family, and Welfare Receipt on Women's Self-Esteem in Young Adulthood." Social Psychology Quarterly 59:80-95.

Edin, Kathryn and Laura Lein. 1997. "Making Ends Meet: How Single Mothers Survive Welfare And Low-Wage Work.” New York: Russell Sage Foundation. 
Ensminger, Margaret. 1996. "Welfare and Psychological Distress: A Longitudinal Study of Afircan American Urban Mothers." Journal of Health and Social Behavior 36(4):246-359.

Fenwick, Rudy, and Mark Tausing. 1994. "The Macroeconomic Context of Job Stress." Journal of Health and Social Behavior 35:266-282.

Frone, Michael R., Marcia Russell, and M. Lynne Cooper. 1993. "Relationship of Work-Family Conflict, Gender, and Alcohol Expectancies to Alcohol Use/Abuse." Journal of Organizational Behavior 14:545-558.

Frone, Michael R. 1999. "Work Stress and Alcohol Use." Alcohol Research and Health 23:284-291.

Garrett, Bowen and John Holohan. 2000. "Health Insurance Coverage After Welfare." Health Affairs. 19:175-184.

Garrett, Bowen and Julie Hudman. 2002. "Women Who Left Welfare: Health Care Coverage, Access and Use of Health Services." The Kaiser Commission on Medicaid and the Uninsured, Washington, DC.

Greeno, Catherine G., and Rena R. Wing. 1994. "Stress-Induced Eating.” Psychological Bulletin 115:444-464.

Grogger, Jeff, Lynn Karoly, and Jacob Klerman. 2002. "Consequences of Welfare Reform: A Research Synthesis.” DRU-2676-Depatment of Health and Human Services.

Guyer, Jocelyn. 2000. "Health Care After Welfare: An Update of the Findings from State-Level Leaver Studies." Washington, DC: Center on Budget and Policy Priorities.

Hamilton, Gayle. 2002. "Moving People from Welfare to Work: Lessons from the National Evaluation of Welfare-to-Work Strategies.” http://aspe.hhs.gov/hsp/NEWWS/synthesis02/

Haskins, Ron. 2001. "Effects of Welfare Reform on Family Income and Poverty." In The New World of Welfare, eds. Rebecca Blank and Ron Haskins. Washington, DC: The Brookings Institution.

Haw, Mary Ann. 1982. "Women, Work and Stress: A Review and Agenda for the Future." Journal of Health and Social Behavior 23:132-144.

Joyce, Theodore, Robert Kaestner, and Sanders Korenman. 2003. "Welfare Reform and Non-marital Fertility in the 1990s: Evidence From Birth Records" Chicago: University of Illinois at Chicago. Unpublished manuscript.

Kaestner, Robert, and Neeraj Kaushal. In press. "Welfare Reform and Health Insurance Coverage of Low-income Families." Journal of Health Economics.

Kassel, Jon D., Carol A. Paronis, and Laura R. Stroud. 2003. "Smoking, Stress, and Negative Affect: Correlation, Causation, and Context Across Stages of Smoking." Psychological Bulletin 129:270-304.

Korn, Edward L. and Barry I. Graubard. 1995. "Analysis of Large Health Surveys: Accounting for the Sampling Design.” Journal of the Royal Statistical Society: Series A. 158:263-295. 
Lennon, Mary Clare. 1994. "Women, Work, and Well-Being: The Importance of Work Conditions." Journal of Health and Social Behavior 35:235-247.

Lennon, Mary Clare, and Sarah Rosenfield. 1992. "Women and Mental Health: The Interaction of Job and Family Conditions." Journal of Health and Social Behavior 33:316-327.

Lerman, Robert. 2001. "Less Educated Single Mothers Achieved High Wage and Employment Gains in the mid 1990s.” Single Parents’ Earnings Monitor October 26, 2001, Urban Institute.

Lillard, L.A. and C.W.A. Panis. 1996. "Marital Status and Mortality: The Role of Health." Demography $33: 313-27$.

Mitchell, Shari L., and Kenneth A. Perkins. 1998. "Interaction of Stress, Smoking, and Dietary Restraint in Women." Physiology and Behavior 64:103-109.

Murray, John E. 2000. "Marital Protection and Marital Selection: Evidence from a Historical-Prospective Sample of American Men” Demography 37(4):511-521.

O'Campo, Patricia, and Lucia Rojas-Smith. 1998. "Welfare Reform and Women's Health: Review of the Literature and Implications for State Policy.” Journal of Public Health Policy 19(4):420-446.

Oliver, Georgina, and Jane Wardle. 1999. "Perceived Effects of Stress on Food Choice." Physiology and Behavior 66:511-515.

Patrick, Donald L., Allen Cheadle, Diane C. Thompson, Paula Diehr, Thomas Koepsell, and Susan Kinne. 1994. "The Validity of Self-reported Smoking: A Review and Meta-analysis." American Journal of Public Health 84: 1086-1093.

Pearling, Leonard I., and Clarice W. Radabaugh. 1976. "Economic Strains and the Coping Function of Alcohol." American Journal of Sociology 82:652-663.

Peirce, Robert S., Michael R. Frone, Marcia Russell, and M. Lynn Cooper. 1994. "Relationship of financial Strain and Psychosocial Resources to Alcohol Use and Abuse: The Mediating Role of Negative Affect and Drinking Motives.” Journal of Health and Social Behavior 35:291-308.

Poikolainen, Kari, Irina Podkletnov, and Hannu Alho. 2002. “Accuracy of Quantity-Frequency and Graduated Frequency Questionnaires in Measuring Alcohol Intake: Comparison with Daily Diary and Commonly Used Laboratory Markers." Alcohol and Alcoholism 36:573-576.

Pugliesi, Karen. 1995. "Work and well-being: Gender Differences in the Psychological Consequences of Employment." Journal of Health and Social Behavior 36:57-71.

Reskin, Barbara F., and Shelley Coverman. 1985. "Sex and Race in the Determinants of Psychophysical Distress: A Reappraisal of the Sex-Role Hypothesis." Social Forces 63:1038-1059.

Rosenfield, Sarah. 1989. "The Effects of Women's Employment: Personal Control and Sex Differences in Mental Health." Journal of Health and Social Behavior 30:77-91.

Ross, Catherine E., and Joan Huber. 1985. "Hardship and Depression." Journal of Health and Social Behavior 26:312-327. 
Ruhm, Christopher J. 1995. "Economic Conditions and Alcohol Problems." Journal of Health Economics 14:583-603.

Ruhm, Christopher J. 2000. “Are Recessions Good for Your Health?” Quarterly Journal of Economics 115(2):617-650.

Ruhm, Christopher J. 2003. "Healthy Living in Hard Times." NBER Working Paper 9468. National Bureau of Economic Research, Cambridge, MA.

Sayette, Michael A. 1999. "Does Drinking Reduce Stress?” Alcohol Research and Health 23:250-255.

Shea, Steven, Aryeh D. Stein, Rafael R. Lantigua, and Charles E. Basch. 1991. "Reliability of the Behavioral Risk Factor Survey in a Triethnic Population." American Journal of Epidemiology 133:489-500.

Smith, James P. 1999. "Healthy Bodies and Thick Wallets: The Dual Relation Between Health and Economic Status." Journal of Economic Perspectives. 13:145-166.

Stein, Aryeh D., Jeanne M. Courval, Ruth I. Lederman, and Steven Shea. 1995. "Reproducibility of REsponses to Telephone Interviews: Demographic Predictors of Discordance in Risk Factor Status." American Journal of Epidemiology 141: 1097-1105.

Thoits, Peggy A. 1986. "Multiple Identities: Examining Gender and Marital Status Differences in Distress." American Sociological Review 51:259-272.

Wagenknecht, Lynne E., Gregory L. Burke, Laura L. Perkins, Nancy J. Haley, Gary D. Friedman. 1992. "Misclassification of Smoking Status in the CARDIA Study: A Comparison of Self-report with Serum Cotinine Levels." American Journal of Public health 82:33-36.

Wardle, Jane, Anderw Steptoe, Georgina Oliver, and Zara Lipsey. 2000. "Stress, Dietary Restraint and Food Intake." Journal of Psychosomatic Research 48:195-202.

Weinstein, Suzanne E., David J. Shide, and Barbara J. Rolls. 1997. "Changes in Food Intake in Response to Stress in Men and Women: Psychological Factors.” Appetite 28:7-18.

Zedlewski, Sheila R. and Pamela Loprest. 2001. "Will TANF Work for the Most Disadvantaged Families?" In The New World of Welfare, edited by Blank, Rebecca M. and Ron Haskins. Washington, D.C.: Brookings Institution Press. 311-328. 
Table 1

Sample Means, BRFSS 1993-1994

\begin{tabular}{|c|c|c|c|c|c|}
\hline \multicolumn{2}{|l|}{ Sample Description } & $\begin{array}{c}\text { Total }^{1} \\
(\mathrm{n}=31,164)^{1}\end{array}$ & $\begin{array}{l}\text { Unmarried } \\
\text { Mothers } \\
(\mathrm{n}=6176)^{1}\end{array}$ & $\begin{array}{c}\text { Married } \\
\text { Mothers } \\
(\mathrm{n}=9340)^{1} \\
\end{array}$ & $\begin{array}{c}\text { Men } \\
(\mathrm{n}=15,648)^{1}\end{array}$ \\
\hline \multicolumn{2}{|l|}{ Age } & 30 & 29 & 32 & 30 \\
\hline Education & HS Diploma & 0.80 & 0.73 & 0.82 & 0.81 \\
\hline \multirow[t]{4}{*}{ Race / ethnicity } & White, Non-hispanic & 0.74 & 0.57 & 0.81 & 0.77 \\
\hline & Black, Non-hispanic & 0.12 & 0.27 & 0.06 & 0.10 \\
\hline & Hispanic & 0.09 & 0.11 & 0.09 & 0.08 \\
\hline & Non-hispanic Other & 0.05 & 0.05 & 0.04 & 0.05 \\
\hline \multirow[t]{2}{*}{ Number of Children } & $1-2$ & 0.57 & 0.74 & 0.71 & 0.43 \\
\hline & 3 or more & 0.21 & 0.26 & 0.29 & 0.13 \\
\hline \multirow[t]{3}{*}{ Number of Adults } & 1 & 0.25 & 0.61 & 0.06 & 0.22 \\
\hline & 2 & 0.61 & 0.25 & 0.85 & 0.61 \\
\hline & 3 or more & 0.14 & 0.14 & 0.09 & 0.17 \\
\hline \multirow[t]{4}{*}{ Employment } & Employed & 0.73 & 0.58 & 0.60 & 0.87 \\
\hline & Unemployed & 0.09 & 0.17 & 0.05 & 0.08 \\
\hline & Not in Labor Force & 0.16 & 0.21 & 0.34 & 0.03 \\
\hline & Unable to Work & 0.02 & 0.04 & 0.01 & 0.02 \\
\hline \multirow[t]{2}{*}{ Health Status } & Fair/Poor Health & 0.10 & 0.15 & 0.09 & 0.10 \\
\hline & Poor Mental Health & 0.38 & 0.49 & 0.42 & 0.32 \\
\hline \multirow[t]{6}{*}{ Health Behaviors } & Daily Smoking & 0.35 & 0.41 & 0.30 & 0.36 \\
\hline & Binge Drinking $^{2}$ & 0.22 & 0.14 & 0.08 & 0.32 \\
\hline & $\begin{array}{l}\text { \# Binge Drinking } \\
\text { Occurrences }^{2}\end{array}$ & 0.85 & 0.45 & 0.19 & 1.41 \\
\hline & Overweight & 0.48 & 0.41 & 0.39 & 0.55 \\
\hline & $\begin{array}{l}\text { Leisure-time } \\
\text { Physical Activity }\end{array}$ & 0.66 & 0.60 & 0.68 & 0.68 \\
\hline & $\begin{array}{l}\text { Regular and } \\
\text { Sustained Exercise }\end{array}$ & 0.17 & 0.15 & 0.17 & 0.17 \\
\hline
\end{tabular}


Table 2

OLS Estimates of the Effect of the Welfare Caseload and Welfare Policies on the Probability of Daily Smoking

\begin{tabular}{|c|c|c|c|c|c|}
\hline \multirow{2}{*}{$\begin{array}{l}\text { Explanatory } \\
\text { Variables }\end{array}$} & \multirow{2}{*}{$\begin{array}{c}\begin{array}{c}\text { Target } \\
\text { Group }\end{array} \\
\text { Unmarried } \\
\text { Mothers }\end{array}$} & \multicolumn{2}{|c|}{ Comparison Group 1} & \multicolumn{2}{|c|}{ Comparison Group 2} \\
\hline & & $\begin{array}{l}\text { Married } \\
\text { Mothers }\end{array}$ & $\begin{array}{l}\text { Difference- } \\
\text { in- } \\
\text { Differences }\end{array}$ & Men & $\begin{array}{l}\text { Difference- } \\
\text { in- } \\
\text { Differences }\end{array}$ \\
\hline Log Caseload & $\begin{array}{c}0.022 \\
(0.025)\end{array}$ & $\begin{array}{c}0.004 \\
(0.011)\end{array}$ & $\begin{array}{c}0.018 \\
(0.026)\end{array}$ & $\begin{array}{l}-0.008 \\
(0.015)\end{array}$ & $\begin{array}{c}0.030 \\
(0.031)\end{array}$ \\
\hline Log Caseload & $\begin{array}{c}0.030 \\
(0.027)\end{array}$ & $\begin{array}{c}0.011 \\
(0.013)\end{array}$ & $\begin{array}{c}0.018 \\
(0.026)\end{array}$ & $\begin{array}{c}0.003 \\
(0.017)\end{array}$ & $\begin{array}{c}0.026 \\
(0.033)\end{array}$ \\
\hline TANF & $\begin{array}{c}0.008 \\
(0.017)\end{array}$ & $\begin{array}{c}0.011 \\
(0.010)\end{array}$ & $\begin{array}{l}-0.003 \\
(0.016)\end{array}$ & $\begin{array}{c}0.018^{*} \\
(0.010)\end{array}$ & $\begin{array}{l}-0.009 \\
(0.018)\end{array}$ \\
\hline AFDC Waiver & $\begin{array}{l}-0.006 \\
(0.013)\end{array}$ & $\begin{array}{c}0.002 \\
(0.011)\end{array}$ & $\begin{array}{l}-0.009 \\
(0.015)\end{array}$ & $\begin{array}{c}0.001 \\
(0.013)\end{array}$ & $\begin{array}{l}-0.007 \\
(0.015)\end{array}$ \\
\hline Log Caseload & $\begin{array}{c}0.036 \\
(0.025)\end{array}$ & $\begin{array}{c}0.019 \\
(0.013)\end{array}$ & $\begin{array}{c}0.017 \\
(0.025)\end{array}$ & $\begin{array}{c}0.008 \\
(0.017)\end{array}$ & $\begin{array}{c}0.028 \\
(0.031)\end{array}$ \\
\hline Time Limits & $\begin{array}{l}-0.004 \\
(0.016)\end{array}$ & $\begin{array}{l}-0.005 \\
(0.011)\end{array}$ & $\begin{array}{c}0.001 \\
(0.018)\end{array}$ & $\begin{array}{c}0.015 \\
(0.010)\end{array}$ & $\begin{array}{l}-0.018 \\
(0.018)\end{array}$ \\
\hline Exemptions & $\begin{array}{c}0.031 \\
(0.022)\end{array}$ & $\begin{array}{c}0.029 \\
(0.019)\end{array}$ & $\begin{array}{c}0.002 \\
(0.028)\end{array}$ & $\begin{array}{c}0.008 \\
(0.016)\end{array}$ & $\begin{array}{c}0.023 \\
(0.027)\end{array}$ \\
\hline Sanctions & $\begin{array}{c}0.027 * \\
(0.015)\end{array}$ & $\begin{array}{c}0.029 * \\
(0.015)\end{array}$ & $\begin{array}{l}-0.002 \\
(0.020)\end{array}$ & $\begin{array}{c}0.013 \\
(0.013)\end{array}$ & $\begin{array}{c}0.014 \\
(0.018)\end{array}$ \\
\hline
\end{tabular}

Notes: Estimates in the three panels are from separate regressions. Each regression controls for family size (number of children and number of adults in the household), age, race, education (high school diploma vs. less-than-high school diploma), state Medicaid eligibility, unemployment rate - current and one-year lag, state real per-capita income, state fixed effects, and state-specific quadratic time trends. Standard errors are in parentheses and they have been constructed under the assumption that observations within a state are not independent.

$* 0.05<\mathrm{p} \leq 0.10, * * \mathrm{p} \leq 0.05$ 
Table 3

OLS Estimates of the Effect of the Welfare Caseload and Welfare Policies on the Probability of Binge Drinking $^{1}$

\begin{tabular}{|c|c|c|c|c|c|}
\hline \multirow{2}{*}{$\begin{array}{c}\text { Explanatory } \\
\text { Variables }\end{array}$} & \multirow{2}{*}{$\begin{array}{c}\text { Target } \\
\text { Group } \\
\text { Unmarried } \\
\text { Mothers }\end{array}$} & \multicolumn{2}{|c|}{ Comparison Group 1} & \multicolumn{2}{|c|}{ Comparison Group 2} \\
\hline & & $\begin{array}{l}\text { Married } \\
\text { Mothers }\end{array}$ & $\begin{array}{l}\text { Difference- } \\
\text { in- } \\
\text { Differences }\end{array}$ & Men & $\begin{array}{l}\text { Difference- } \\
\text { in- } \\
\text { Differences }\end{array}$ \\
\hline Log Caseload & $\begin{array}{l}0.051 * * \\
(0.022)\end{array}$ & $\begin{array}{c}0.001 \\
(0.010)\end{array}$ & $\begin{array}{c}0.051^{*} \\
(0.025)\end{array}$ & $\begin{array}{l}-0.017 \\
(0.014)\end{array}$ & $\begin{array}{l}0.069^{* *} \\
(0.025)\end{array}$ \\
\hline Log Caseload & $\begin{array}{l}0.050 * * \\
(0.023)\end{array}$ & $\begin{array}{l}-0.005 \\
(0.010)\end{array}$ & $\begin{array}{l}0.056^{* *} \\
(0.026)\end{array}$ & $\begin{array}{l}-0.022 \\
(0.017)\end{array}$ & $\begin{array}{l}0.072 * * \\
(0.026)\end{array}$ \\
\hline TANF & $\begin{array}{l}-0.008 \\
(0.018)\end{array}$ & $\begin{array}{l}-0.012 * \\
(0.007)\end{array}$ & $\begin{array}{c}0.004 \\
(0.019)\end{array}$ & $\begin{array}{l}-0.011 \\
(0.019)\end{array}$ & $\begin{array}{c}0.003 \\
(0.023)\end{array}$ \\
\hline AFDC Waiver & $\begin{array}{l}-0.024 \\
(0.018)\end{array}$ & $\begin{array}{l}-0.002 \\
(0.012)\end{array}$ & $\begin{array}{l}-0.022 \\
(0.020)\end{array}$ & $\begin{array}{l}-0.008 \\
(0.019)\end{array}$ & $\begin{array}{l}-0.017 \\
(0.028)\end{array}$ \\
\hline Log Caseload & $\begin{array}{l}0.057 * * \\
(0.023)\end{array}$ & $\begin{array}{l}-0.001 \\
(0.010)\end{array}$ & $\begin{array}{l}0.058 * * \\
(0.026)\end{array}$ & $\begin{array}{l}-0.018 \\
(0.017)\end{array}$ & $\begin{array}{l}0.075 * * \\
(0.026)\end{array}$ \\
\hline Time Limits & $\begin{array}{l}-0.003 \\
(0.020)\end{array}$ & $\begin{array}{l}-0.008 \\
(0.010)\end{array}$ & $\begin{array}{c}0.005 \\
(0.022)\end{array}$ & $\begin{array}{l}-0.000 \\
(0.023)\end{array}$ & $\begin{array}{l}-0.003 \\
(0.025)\end{array}$ \\
\hline Exemptions & $\begin{array}{c}0.005 \\
(0.023)\end{array}$ & $\begin{array}{l}0.026^{*} \\
(0.013)\end{array}$ & $\begin{array}{l}-0.021 \\
(0.028)\end{array}$ & $\begin{array}{l}-0.007 \\
(0.030)\end{array}$ & $\begin{array}{c}0.012 \\
(0.034)\end{array}$ \\
\hline Sanctions & $\begin{array}{c}0.022 \\
(0.021)\end{array}$ & $\begin{array}{l}-0.003 \\
(0.014)\end{array}$ & $\begin{array}{c}0.024 \\
(0.024)\end{array}$ & $\begin{array}{c}0.001 \\
(0.026)\end{array}$ & $\begin{array}{c}0.021 \\
(0.032)\end{array}$ \\
\hline
\end{tabular}

Notes: Estimates in the three panels are from separate regressions. Each regression controls for family size (number of children and number of adults in the household), age, race, education (high school diploma vs. less-than-high school diploma), state Medicaid eligibility, unemployment rate - current and one-year lag, state real per-capita income, state fixed effects, and state-specific quadratic time trends. Standard errors are in parentheses and they have been constructed under the assumption that observations within a state are not independent.

$* 0.05<\mathrm{p} \leq 0.10, * * \mathrm{p} \leq 0.05$

${ }^{1}$ Greater than or equal to 5 drinks on at least one occasion in the last month. Data are from odd years, $1993-2001$. 
Table 4

OLS Estimates of the Effect of the Welfare Caseload and Welfare Policies on the Probability of Engaging in Regular and Sustained Physical Activity ${ }^{1}$

\begin{tabular}{|c|c|c|c|c|c|}
\hline \multirow{2}{*}{$\begin{array}{c}\text { Explanatory } \\
\text { Variables }\end{array}$} & \multirow{2}{*}{$\begin{array}{c}\text { Target } \\
\text { Group } \\
\text { Unmarried } \\
\text { Mothers }\end{array}$} & \multicolumn{2}{|c|}{ Comparison Group 1} & \multicolumn{2}{|c|}{ Comparison Group 2} \\
\hline & & $\begin{array}{l}\text { Married } \\
\text { Mothers }\end{array}$ & $\begin{array}{l}\text { Difference- } \\
\text { in- } \\
\text { Differences }\end{array}$ & Men & $\begin{array}{l}\text { Difference- } \\
\text { in- } \\
\text { Differences }\end{array}$ \\
\hline Log Caseload & $\begin{array}{l}-0.040 \\
(0.025)\end{array}$ & $\begin{array}{c}0.023 * \\
(0.029)\end{array}$ & $\begin{array}{l}-0.063 \\
(0.044)\end{array}$ & $\begin{array}{c}0.018 \\
(0.016)\end{array}$ & $\begin{array}{l}-0.058^{* *} \\
(0.026)\end{array}$ \\
\hline Log Caseload & $\begin{array}{l}-0.053 * * \\
(0.026)\end{array}$ & $\begin{array}{c}0.015 \\
(0.032)\end{array}$ & $\begin{array}{l}-0.067 \\
(0.047)\end{array}$ & $\begin{array}{c}0.017 \\
(0.018)\end{array}$ & $\begin{array}{l}-0.070 * * \\
(0.028)\end{array}$ \\
\hline TANF & $\begin{array}{l}-0.006 \\
(0.017)\end{array}$ & $\begin{array}{l}-0.017 \\
(0.021)\end{array}$ & $\begin{array}{c}0.011 \\
(0.020)\end{array}$ & $\begin{array}{l}-0.015 \\
(0.011)\end{array}$ & $\begin{array}{c}0.009 \\
(0.022)\end{array}$ \\
\hline AFDC Waiver & $\begin{array}{c}0.014 \\
(0.021)\end{array}$ & $\begin{array}{l}-0.014 \\
(0.016)\end{array}$ & $\begin{array}{c}0.028 \\
(0.022)\end{array}$ & $\begin{array}{l}-0.024^{* *} \\
(0.010)\end{array}$ & $\begin{array}{c}0.038 \\
(0.024)\end{array}$ \\
\hline Log Caseload & $\begin{array}{l}-0.030 \\
(0.029)\end{array}$ & $\begin{array}{l}-0.003 \\
(0.036)\end{array}$ & $\begin{array}{l}-0.027 \\
(0.051)\end{array}$ & $\begin{array}{c}0.020 \\
(0.021)\end{array}$ & $\begin{array}{l}-0.050 \\
(0.034)\end{array}$ \\
\hline Time Limits & $\begin{array}{c}0.025 \\
(0.019)\end{array}$ & $\begin{array}{l}-0.014 \\
(0.020)\end{array}$ & $\begin{array}{c}0.039^{* *} \\
(0.018)\end{array}$ & $\begin{array}{c}0.001 \\
(0.011)\end{array}$ & $\begin{array}{c}0.024 \\
(0.021)\end{array}$ \\
\hline Exemptions & $\begin{array}{l}-0.045 \\
(0.032)\end{array}$ & $\begin{array}{l}-0.023 \\
(0.025)\end{array}$ & $\begin{array}{l}-0.022 \\
(0.033)\end{array}$ & $\begin{array}{l}-0.006 \\
(0.023)\end{array}$ & $\begin{array}{l}-0.040 \\
(0.035)\end{array}$ \\
\hline Sanctions & $\begin{array}{c}0.016 \\
(0.021)\end{array}$ & $\begin{array}{l}-0.007 \\
(0.021)\end{array}$ & $\begin{array}{c}0.023 \\
(0.025)\end{array}$ & $\begin{array}{c}0.008 \\
(0.017)\end{array}$ & $\begin{array}{c}0.008 \\
(0.021)\end{array}$ \\
\hline
\end{tabular}

Notes: Estimates in the three panels are from separate regressions. Each regression controls for family size (number of children and number of adults in the household), age, race, education (high school diploma vs. less-than-high school diploma), state Medicaid eligibility, unemployment rate - current and one-year lag, state real per-capita income, state fixed effects, and state-specific quadratic time trends. Standard errors are in parentheses and they have been constructed under the assumption that observations within a state are not independent.

$* 0.05<\mathrm{p} \leq 0.10, * * \mathrm{p} \leq 0.05$

${ }^{1}$ Data are from even years, $1994-2000$ 
Table 5

OLS Estimates of the Effect of State Welfare Policies on the Probability of Poor Mental Health

\begin{tabular}{|c|c|c|c|c|c|}
\hline \multirow{2}{*}{$\begin{array}{l}\text { Explanatory } \\
\text { Variables }\end{array}$} & \multirow{2}{*}{$\begin{array}{c}\text { Target } \\
\text { Group } \\
\text { Unmarried } \\
\text { Mothers }\end{array}$} & \multicolumn{2}{|c|}{ Comparison Group 1} & \multicolumn{2}{|c|}{ Comparison Group 2} \\
\hline & & $\begin{array}{l}\text { Married } \\
\text { Mothers }\end{array}$ & $\begin{array}{l}\text { Difference- } \\
\text { in- } \\
\text { Differences }\end{array}$ & Men & $\begin{array}{l}\text { Difference- } \\
\text { in- } \\
\text { Differences }\end{array}$ \\
\hline Log Caseload & $\begin{array}{c}0.012 \\
(0.026)\end{array}$ & $\begin{array}{l}-0.023 \\
(0.024)\end{array}$ & $\begin{array}{c}0.035 \\
(0.028)\end{array}$ & $\begin{array}{l}-0.013 \\
(0.020)\end{array}$ & $\begin{array}{c}0.025 \\
(0.030)\end{array}$ \\
\hline Log Caseload & $\begin{array}{c}0.008 \\
(0.027)\end{array}$ & $\begin{array}{l}-0.035 \\
(0.028)\end{array}$ & $\begin{array}{c}0.043 \\
(0.030)\end{array}$ & $\begin{array}{l}-0.017 \\
(0.021)\end{array}$ & $\begin{array}{c}0.025 \\
(0.030)\end{array}$ \\
\hline TANF & $\begin{array}{l}-0.015 \\
(0.016)\end{array}$ & $\begin{array}{l}-0.017 \\
(0.015)\end{array}$ & $\begin{array}{c}0.002 \\
(0.020)\end{array}$ & $\begin{array}{l}-0.016 \\
(0.013)\end{array}$ & $\begin{array}{c}0.001 \\
(0.016)\end{array}$ \\
\hline AFDC Waiver & $\begin{array}{l}-0.019 \\
(0.014)\end{array}$ & $\begin{array}{c}0.002 \\
(0.013)\end{array}$ & $\begin{array}{l}-0.020 \\
(0.015)\end{array}$ & $\begin{array}{l}-0.024 * * \\
(0.010)\end{array}$ & $\begin{array}{c}0.005 \\
(0.016)\end{array}$ \\
\hline Log Caseload & $\begin{array}{c}0.014 \\
(0.028)\end{array}$ & $\begin{array}{l}-0.027 \\
(0.028)\end{array}$ & $\begin{array}{c}0.041 \\
(0.031)\end{array}$ & $\begin{array}{l}-0.009 \\
(0.023)\end{array}$ & $\begin{array}{c}0.023 \\
(0.030)\end{array}$ \\
\hline Time Limits & $\begin{array}{l}-0.001 \\
(0.017)\end{array}$ & $\begin{array}{c}0.001 \\
(0.015)\end{array}$ & $\begin{array}{l}-0.002 \\
(0.020)\end{array}$ & $\begin{array}{c}0.005 \\
(0.012)\end{array}$ & $\begin{array}{l}-0.006 \\
(0.016)\end{array}$ \\
\hline Exemptions & $\begin{array}{c}0.005 \\
(0.028)\end{array}$ & $\begin{array}{l}-0.001 \\
(0.017)\end{array}$ & $\begin{array}{c}0.006 \\
(0.029)\end{array}$ & $\begin{array}{l}0.033 * * \\
(0.016)\end{array}$ & $\begin{array}{l}-0.028 \\
(0.026)\end{array}$ \\
\hline Sanctions & $\begin{array}{c}0.003 \\
(0.023)\end{array}$ & $\begin{array}{l}-0.014 \\
(0.013)\end{array}$ & $\begin{array}{c}0.017 \\
(0.022)\end{array}$ & $\begin{array}{l}-0.024 * * \\
(0.012)\end{array}$ & $\begin{array}{c}0.026 \\
(0.020)\end{array}$ \\
\hline
\end{tabular}

Notes: Estimates in the three panels are from separate regressions. Each regression controls for family size (number of children and number of adults in the household), age, race, education (high school diploma vs. less-than-high school diploma), state Medicaid eligibility, unemployment rate - current and one-year lag, state real per-capita income, state fixed effects, and state-specific quadratic time trends. Standard errors are in parentheses and they have been constructed under the assumption that observations within a state are not independent.

$* 0.05<\mathrm{p} \leq 0.10, * * \mathrm{p} \leq 0.05$ 
Table 6

OLS Estimates of the Effect of State Welfare Policies on the Probability of Fair or Poor Health

\begin{tabular}{|c|c|c|c|c|c|}
\hline \multirow{2}{*}{$\begin{array}{l}\text { Explanatory } \\
\text { Variables }\end{array}$} & \multirow{2}{*}{$\begin{array}{c}\text { Target } \\
\text { Group } \\
\text { Unmarried } \\
\text { Mothers }\end{array}$} & \multicolumn{2}{|c|}{ Comparison Group 1} & \multicolumn{2}{|c|}{ Comparison Group 2} \\
\hline & & $\begin{array}{l}\text { Married } \\
\text { Mothers }\end{array}$ & $\begin{array}{l}\text { Difference- } \\
\text { in- } \\
\text { Differences }\end{array}$ & Men & $\begin{array}{l}\text { Difference- } \\
\text { in- } \\
\text { Differences }\end{array}$ \\
\hline Log Caseload & $\begin{array}{l}-0.016 \\
(0.014)\end{array}$ & $\begin{array}{c}0.006 \\
(0.008)\end{array}$ & $\begin{array}{l}-0.022 \\
(0.016)\end{array}$ & $\begin{array}{l}-0.006 \\
(0.009)\end{array}$ & $\begin{array}{l}-0.011 \\
(0.015)\end{array}$ \\
\hline Log Caseload & $\begin{array}{l}-0.004 \\
(0.015)\end{array}$ & $\begin{array}{c}0.004 \\
(0.009)\end{array}$ & $\begin{array}{l}-0.008 \\
(0.018)\end{array}$ & $\begin{array}{l}-0.007 \\
(0.009)\end{array}$ & $\begin{array}{c}0.002 \\
(0.017)\end{array}$ \\
\hline TANF & $\begin{array}{c}0.018 \\
(0.011)\end{array}$ & $\begin{array}{l}-0.005 \\
(0.007)\end{array}$ & $\begin{array}{c}0.023^{*} \\
(0.013)\end{array}$ & $\begin{array}{l}-0.002 \\
(0.005)\end{array}$ & $\begin{array}{c}0.020 \\
(0.013)\end{array}$ \\
\hline AFDC Waiver & $\begin{array}{c}0.000 \\
(0.009)\end{array}$ & $\begin{array}{l}-0.007 \\
(0.007)\end{array}$ & $\begin{array}{c}0.007 \\
(0.010)\end{array}$ & $\begin{array}{l}-0.001 \\
(0.005)\end{array}$ & $\begin{array}{c}0.002 \\
(0.010)\end{array}$ \\
\hline Log Caseload & $\begin{array}{l}-0.000 \\
(0.016)\end{array}$ & $\begin{array}{c}0.005 \\
(0.009)\end{array}$ & $\begin{array}{l}-0.005 \\
(0.018)\end{array}$ & $\begin{array}{l}-0.001 \\
(0.009)\end{array}$ & $\begin{array}{c}0.001 \\
(0.016)\end{array}$ \\
\hline Time Limits & $\begin{array}{c}0.024 \\
(0.010)\end{array}$ & $\begin{array}{l}-0.001 \\
(0.007)\end{array}$ & $\begin{array}{c}0.025^{*} \\
(0.014)\end{array}$ & $\begin{array}{c}0.002 \\
(0.005)\end{array}$ & $\begin{array}{c}0.022 * \\
(0.012)\end{array}$ \\
\hline Exemptions & $\begin{array}{l}-0.005 \\
(0.016)\end{array}$ & $\begin{array}{l}-0.006 \\
(0.011)\end{array}$ & $\begin{array}{c}0.001 \\
(0.016)\end{array}$ & $\begin{array}{c}0.000 \\
(0.011)\end{array}$ & $\begin{array}{l}-0.005 \\
(0.016)\end{array}$ \\
\hline Sanctions & $\begin{array}{c}0.004 \\
(0.011)\end{array}$ & $\begin{array}{c}0.003 \\
(0.009)\end{array}$ & $\begin{array}{c}0.000 \\
(0.014)\end{array}$ & $\begin{array}{c}0.007 \\
(0.008)\end{array}$ & $\begin{array}{l}-0.004 \\
(0.012)\end{array}$ \\
\hline
\end{tabular}

Notes: Estimates in the three panels are from separate regressions. Each regression controls for family size (number of children and number of adults in the household), age, race, education (high school diploma vs. less-than-high school diploma), state Medicaid eligibility, unemployment rate - current and one-year lag, state real per-capita income, state fixed effects, and state-specific quadratic time trends. Standard errors are in parentheses and they have been constructed under the assumption that observations within a state are not independent.

$* 0.05<\mathrm{p} \leq 0.10, * * \mathrm{p} \leq 0.05$ 
Appendix Table 1

Sample Means, BRFSS 1993-2001

\begin{tabular}{|c|c|c|c|c|c|}
\hline \multicolumn{2}{|l|}{ Sample Description } & $\begin{array}{c}\text { Total }^{1} \\
(\mathrm{n}=67,698)\end{array}$ & $\begin{array}{c}\text { Unmarried } \\
\text { Mothers } \\
(\mathrm{n}=36,274)\end{array}$ & $\begin{array}{c}\text { Married } \\
\text { Mothers } \\
(\mathrm{n}=48,199)\end{array}$ & $\begin{array}{c}\text { Men } \\
(\mathrm{n}=83,225)\end{array}$ \\
\hline \multicolumn{2}{|l|}{ Age } & 30 & 29 & 32 & 30 \\
\hline Education & HS Diploma & 0.79 & 0.74 & 0.81 & 0.80 \\
\hline \multirow[t]{4}{*}{ Race / ethnicity } & White, Non-hispanic & 0.71 & 0.55 & 0.77 & 0.74 \\
\hline & Black, Non-hispanic & 0.12 & 0.25 & 0.06 & 0.09 \\
\hline & Hispanic & 0.13 & 0.15 & 0.13 & 0.12 \\
\hline & Non-hispanic Other & 0.05 & 0.05 & 0.04 & 0.05 \\
\hline \multirow[t]{2}{*}{ Number of Children } & $1-2$ & 0.56 & 0.72 & 0.69 & 0.42 \\
\hline & 3 or more & 0.22 & 0.28 & 0.31 & 0.14 \\
\hline \multirow[t]{3}{*}{ Number of Adults } & 1 & 0.25 & 0.59 & 0.06 & 0.22 \\
\hline & 2 & 0.60 & 0.28 & 0.84 & 0.60 \\
\hline & 3 or more & 0.15 & 0.13 & 0.10 & 0.18 \\
\hline \multirow[t]{4}{*}{ Employment } & Employed & 0.75 & 0.64 & 0.61 & 0.88 \\
\hline & Unemployed & 0.08 & 0.14 & 0.05 & 0.07 \\
\hline & Not in Labor Force & 0.14 & 0.17 & 0.32 & 0.02 \\
\hline & Unable to Work & 0.03 & 0.05 & 0.02 & 0.03 \\
\hline \multirow[t]{2}{*}{ Health Status } & Fair/Poor Health & 0.11 & 0.15 & 0.10 & 0.10 \\
\hline & Poor Mental Health & 0.38 & 0.49 & 0.41 & 0.32 \\
\hline \multirow[t]{6}{*}{ Health Behaviors } & Daily Smoking & 0.33 & 0.38 & 0.28 & 0.33 \\
\hline & Binge Drinking ${ }^{2}$ & 0.22 & 0.14 & 0.08 & 0.33 \\
\hline & $\begin{array}{l}\text { \# Binge Drinking } \\
\text { Occurrences }^{2}\end{array}$ & 0.91 & 0.43 & 0.20 & 1.54 \\
\hline & Overweight & 0.53 & 0.47 & 0.45 & 0.59 \\
\hline & $\begin{array}{l}\text { Leisure-time } \\
\text { Physical Activity }\end{array}$ & 0.67 & 0.60 & 0.66 & 0.70 \\
\hline & $\begin{array}{l}\text { Regular and } \\
\text { Sustained Exercise }\end{array}$ & 0.14 & 0.13 & 0.14 & 0.15 \\
\hline
\end{tabular}

Notes: ${ }^{1}$ Unless otherwise indicated, sample sizes pertain to the combined total for years 1993-2001

${ }^{2}$ Data are from odd years only, 1993-2001. Sample sizes are: 91,911 (total); 19,715 (Unmarried Mothers); 26,609 (Married Mothers); 5,587 (Men)

${ }^{3}$ Data are from 1994, 1996, 1998, 2000, and 2001. Sample sizes are: 97,376 (total); 21,727

(Unmarried Mothers); 27,549 (Married Mothers); 48,100 (Men)

${ }^{4}$ Data are from 1994, 1996, 1998, and 2000. Sample sizes are: 70,357 (total); 15,528 (Unmarried Mothers); 20,213 (Married Mothers); 34,616 (Men) 